\title{
Caudex growth and phenology of Cyathea atrovirens (Langsd. \& Fisch.) Domin (Cyatheaceae) in secondary forest, southern Brazil
}

\author{
Schmitt, JL. ${ }^{a, b *}$ and Windisch, $P G .^{b}$ \\ aPrograma de Pós-Graduação em Qualidade Ambiental, Laboratório de Botânica, \\ Universidade Feevale, Rod. RS 239, 2755, CEP 93352-000, Novo Hamburgo, RS, Brazil \\ bPrograma de Pós-Graduação em Botânica, Universidade Federal do Rio Grande do Sul - UFRGS, \\ Av. Bento Gonçalves, 9500, CEP 91501-970, Porto Alegre, RS, Brazil \\ *e-mail: jairols@feevale.br \\ Received May 11, 2011 - Accepted July 18, 2011 - Distributed May 31, 2012
}

(With 3 figures)

\begin{abstract}
The leaf production and senescence, formation and release of spores of Cyathea atrovirens (Langsd. \& Fisch.) Domin were analysed based on the monthly monitoring of 50 plants growing in a secondary forest, in the municipality of Novo Hamburgo, in the state of Rio Grande do Sul, during the year 2004. The caudex height and number of mature and fertile leaves were recorded annually in 2004-09. In 2004, monthly production and senescence of leaves were concomitant, without total leaf abscission. Population synchrony at emergence $(Z=0.86)$ and leaf senescence $(Z=0.82)$ increased in spring but did not correlate with temperature and photoperiod. All individuals were fertile and the sporangia production and spore liberation presented higher and equal synchrony $(Z=0.84)$ respectively in spring and summer. Sporangia production was related with temperature and photoperiod, however taller plants did not produce more fertile leaves. Phenological events analysed were not influenced by precipitation, as expected for forests in non-seasonal climate. Over five years (2004-09), the annual mean caudex growth varied between 1.19 and $2.50 \mathrm{~cm}_{\text {.year }}^{-1}$ and the plants appeared to have an ability to maintain a relatively stable amount of leaves throughout this period.
\end{abstract}

Keywords: monitoring, growth rates, tree fern.

\section{Crescimento do cáudice e fenologia de Cyathea atrovirens (Langsd. \& Fisch.) Domin (Cyatheaceae) em floresta secundária, no sul do Brasil}

\section{Resumo}

A produção e a senescência de folhas, a formação e a liberação de esporos de Cyathea atrovirens (Langsd. \& Fisch.) Domin, durante o ano de 2004, foram analisadas a partir do monitoramento mensal de 50 plantas, crescendo em floresta secundária, no município de Novo Hamburgo, Estado do Rio Grande do Sul, Brasil. A altura do cáudice e o número de folhas foram mensurados anualmente de 2004-2009. Em 2004, a produção e a senescência mensal de folhas foram concomitantes, evitando a abscisão foliar total. A sincronia da população na renovação $(Z=0,86)$ e na senescência foliar $(Z=0,82)$ aumentou na primavera, porém esses eventos não se relacionaram com temperatura e fotoperíodo. Todos os indivíduos estavam férteis e a produção de esporângios e a liberação de esporos apresentaram uma sincronia maior e igual $(Z=0,84)$, respectivamente, na primavera e no verão. A produção de esporângios se relacionou com temperatura e fotoperíodo, porém plantas mais altas não produziram mais folhas férteis. Os eventos fenológicos analisados não foram influenciados pela precipitação, tal como esperado para florestas sob clima não sazonal. Durante cinco anos (2004-2009), a média anual do crescimento do cáudice variou de 1,19 a 2,50 cm.ano ${ }^{-1}$ e as plantas demonstraram capacidade de manter o número de folhas relativamente estável ao longo do período.

Palavras-chave: monitoramento, taxas de crescimento, samambaia arborescente.

\section{Introduction}

Tree ferns represent an important understory component of tropical forests (Page, 1979; Tryon and Tryon, 1982). Cyatheaceae and Dicksoniaceae encompass the vast majority of species of caudex forming ferns (Fernandes, 2003), with ca. 180 species occurring in the Neoptropics (Tryon and Tryon, 1982). Fernandes (1997) reports 20 species in south and southeastern Brazil, six of which occur in the state of Rio Grande do Sul. There are few studies on the phenology of these ferns (Mehltreter and Palácio-Rios, 2003; Mehltreter and García-Franco, 2008) and most 
phenological studies in this region have focussed on arboreal angiosperms (Pedroni et al., 2002). Seasonal changes in precipitation (rainfall and fog) and temperature are major factors affecting leaf development and spore production (Mehltreter, 2006). Chiou et al. (2001) and Schmitt et al. (2009) also consider the influence of the photoperiod in phenological events in ferns. The wind also can affect the phenology of plants, although mainly of those that reach the canopy (Richards, 1952). Seasonal drought and changes in water availability have been identified as the principal external factors controlling the periodic rhythms of tropical seasonal forests (Reich and Borchert 1984).

Caudex growth in arborescent ferns varies greatly between species and habitats (Arens, 2001; Schmitt and Windisch, 2007; Mehltreter and García-Franco, 2008), and some species grow faster in secondary forests than in primary ones (Bittner and Breckle, 1995). Some studies have indicated the potential for perennial development in some species, through the continued growth of the fallen caudices subsequent to their toppling (Walker and Aplet, 1994; Windisch et al., 2008).

In the Neotropics, studies including phenological data for Cyatheaceae species were presented by Mehltreter and García-Franco (2008) in Mexico; Conant (1976); Tanner (1983); Bittner and Breckle (1995) in Central America; Arens (2001) in South America; Schmitt and Windisch (2001, 2003, 2006a, b, 2007); Lehn and Leuchtenberg (2008) specifically in south Brazil. Cyathea atrovirens (Langsd. \& Fisch.) Domin occurs in a wide range of habitats, in south and southeastern Brazil extending into Paraguay, Uruguay and Argentina (Ponce, 1996). In Rio Grande do Sul, this species is commonly found in swampy forests in coastal plains, and in dense forests of mountain slopes in the northeastern region (Sehnem, 1978).

Cyathea atrovirens forms caudices as high as $6 \mathrm{~m}$ tall, with a sheath of adventitious roots at the base (up to $25 \mathrm{~cm}$ in diameter). Leaves are up to $3 \mathrm{~m}$ long with aculeus on the petioles and abaxially on the rachises and pinna-rachises. Petioles are up to $1.10 \mathrm{~m}$ long and the laminas are bipinnate-pinnatifid to pinatilobate (Sehem, 1978; Fernandes, 1997). Plants are harvested for their fibrous adventitious roots which are used as substrate for the cultivation of decorative plants (Fernandes, 2000). Cut leaves are used for decoration (Tryon and Tryon, 1982) and entire plants are used in gardening.

Most of the information on Cyathea atrovirens is found in the taxonomic literature (Tryon and Tryon, 1982; Fernandes, 2000), anatomy (Sant'Anna et al., 2001) floristic studies (Sehnem, 1978; Fontana et al., 2007), and in a study of native ornamental plants (Hoehne, 1930). Spore germination and early stages of gametophytic development of $C$. atrovirens were studied by Rechenmacher et al. (2010). Lehn and Leuchetenberg (2008) monitored a population of C. atrovirens in an open deforested moist ravine exposed to burning, in Rio Grande do Sul. The present study of C. atrovirens aims to determine 1) caudex growth rates; 2) leaf production, expansion and senescence rates; 3) spore production and release periods; 4) the intensity of the simultaneous occurrence of each phenologic event as well as the influence of temperature, photoperiod and precipitation over it, based on the monitoring of a population in a secondary forest in southern Brazil. Considering that in southern Brazil there is no dry season, photoperiod and temperature were expected to be important abiotic factors affecting the phenology of the tree fern analysed. Such basic life history information is critical to understanding its entire life cycle and will provide the basis for plant production used in gardening.

\section{Material and Methods}

Study area - Field work was conducted at the Henrique Luís Roessler Municipal Park (2940'54”' S and $51^{\circ} 06^{\prime} 56^{\prime \prime} \mathrm{W}$, alt. ca. $20 \mathrm{~m}$ ), in the municipality of Novo Hamburgo, in the state of Rio Grande do Sul, Brazil.
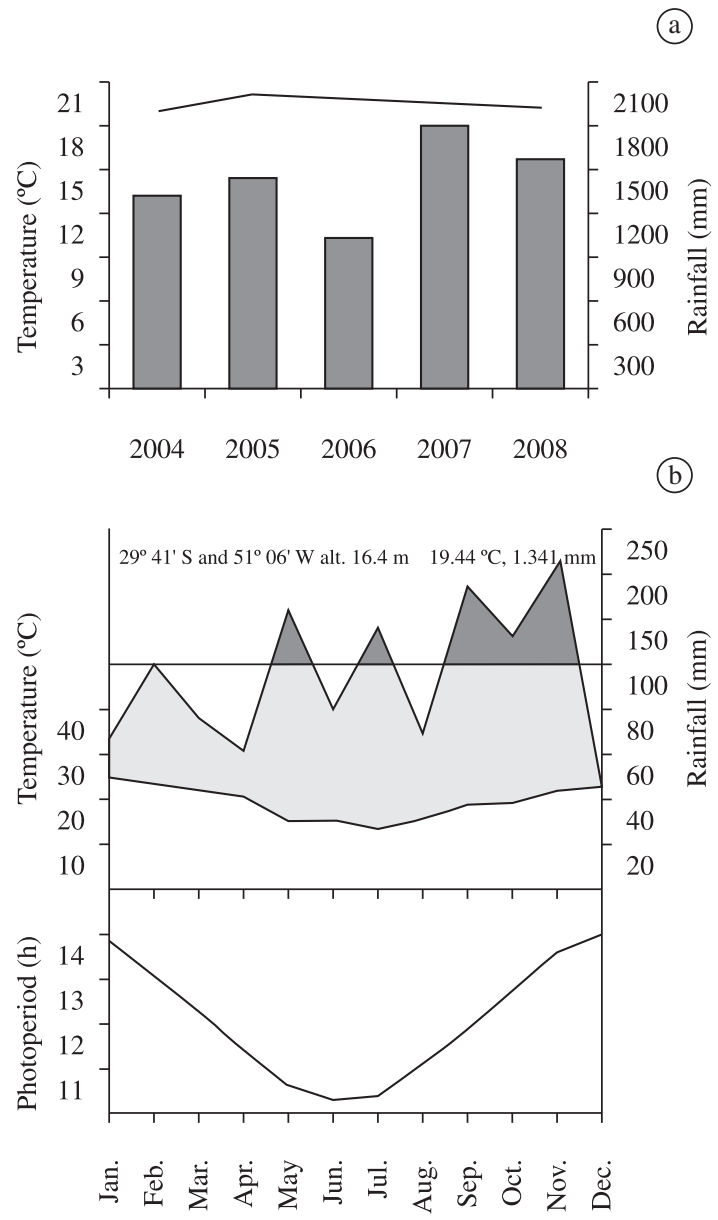

Figure 1. Annual rainfall and mean temperature from 2004 to 2008 (a); meteorological diagram and monthly mean photoperiod (b) from January to December 2004. Climate data were obtained from Campo Bom city meteorological station (29 41' $\mathrm{S}$ and 51 ${ }^{\circ}$ 06' W alt. $16.4 \mathrm{~m}$ ), Rio Grande do Sul, Brazil. Photoperiod measurements were obtained from the interactive yearbook of the Brazilian National Observatory (http://euler.on.br/ephemeris/index.php). 
The park, of 54 ha, is located in a region previously used for agricultural purposes that now includes dry fields, wet areas and secondary forests (Weisheimer et al., 1996). Some characteristic tree species that can be cited are Schinus terebinthifolius Raddi, Myrsine coriacea (Sw.). R. Br., M. umbellate Mart., Guarea macrophylla Vahl, Psidium cattleyanum Sabine, Ocotea pulchella (Nees) Mez, Casearia sylvestris Sw. and Cupania vernalis Cambess. The reddish-brown soil consists of slightly compressed, very fine sand mixed with clay and organic matter (Weisheimer et al., 1996). The climate, according to the Koeppen classification, corresponds to the Cfa type, with the warmest month's mean temperature above $22^{\circ} \mathrm{C}$ (Moreno, 1961) and rainfall distributed throughout the year. In 2004 the mean annual temperature was $19.4{ }^{\circ} \mathrm{C}$ and the mean of the warmest month (January) was $25.1{ }^{\circ} \mathrm{C}$. The coldest month was July $\left(12.9^{\circ} \mathrm{C}\right)$ and the annual accumulated rainfall was $1,341 \mathrm{~mm}$. Mean day length ranged from 14.01 hours in December to 10.26 hours recorded in June. During the five years covered in this study (2004 to 2009), mean annual temperature ranged from 19.3 to $20{ }^{\circ} \mathrm{C}$ and rainfall from 1,098 to $1,781 \mathrm{~mm}$ (Figure 1 ).

Individual tagging - In January 2004, 50 individuals of Cyathea atrovirens were tagged using wood stakes with numbered aluminum tags placed in the soil near each plant. Plants were selected inside $32(2 \times 5 \mathrm{~m})$ plots, along two transections, with 18 and 14 plots each. These plots were previously marked in a secondary forest that reached an intermediate stage of regeneration, characterised by a low canopy (less than $8 \mathrm{~m}$ high), near a stream crossing the park. The voucher specimen (HASU 93510) was deposited in the Herbarium Anchieta (PACA), in São Leopoldo, Rio Grande do Sul.

Monthly monitoring - During the first year (2004), croziers, mature (fully expanded green pinnae), fertile and senescent leaves (with all pinnae dried pinnae or only the remaining petiole bases) were counted monthly in all individuals in order to determine production and senescence rates. Young croziers were marked with plastic rings and their development was followed monthly until its total expansion in order to determine leaf growth rates. We recorded the period in which individuals had leaves with immature (green) sporangia, developed (but still closed) sporangia, until the opening stage with spore release.

Annual monitoring - To calculate the annual growth rates, plant height was measured from caudex apex to ground level in January 2004, and at intervals of 12, 24, 36,48 and 60 months. The number of mature and fertile leaves was thereafter recorded annually.

Statistical analysis - Using the statistical program SPSS version 15.0, the Spearman post correlation test was applied to determine the relationship between number of fertile leaves with the caudex height and phenological events with temperature, photoperiod and precipitation. The synchrony of the population phenophases was measured by the synchrony index (Z) adapted from Augspurger (1983) by Pedroni et al. (2002). The synchrony is perfect when $Z=1$, i.e. all individuals of the population are simultaneously in the same phenophase, while no synchrony in the population corresponds to $Z=0$. Data on mean annual caudex growth rates mean number of mature and fertile leaves in January throughout the years for the five-year (2004-09) period were tested for normality and homogeneity using the Kolmogorov-Smirnov test and Levene's test. Repeated ANOVA measures were applied to compare the annual data (2004-09) meeting the normality and homogeneity assumption. Differences between annual means were verified using the multiple comparisons Bonferroni test, with a 5\% significance level (Zar, 1999). Annual caudex growth rates were transformed into $\operatorname{Ln}($ rate +1$)$ to normalise data distribution.

\section{Results}

Monthly monitoring - During 2004, most individuals had concomitant emergence and leaf senescence, reflected in the similar annual synchrony rates of $Z=0.65$ and $Z=0.56$, respectively, without total absence of leaves. Plants produced in average $8.6 \pm 3.46$ leaves.year $^{-1}$, ranging from 3 to 19 leaves.year ${ }^{-1}$. During May no leaf production was recorded. However, during spring the highest monthly means for leaf emergence were observed, with the maximum mean of $2.26 \pm 1.21$ leaves per plant recorded in September (Figure 2). In September and October $\geq 84 \%$ of marked individuals produced leaves (Figure 3), with an index of synchrony higher than the annual

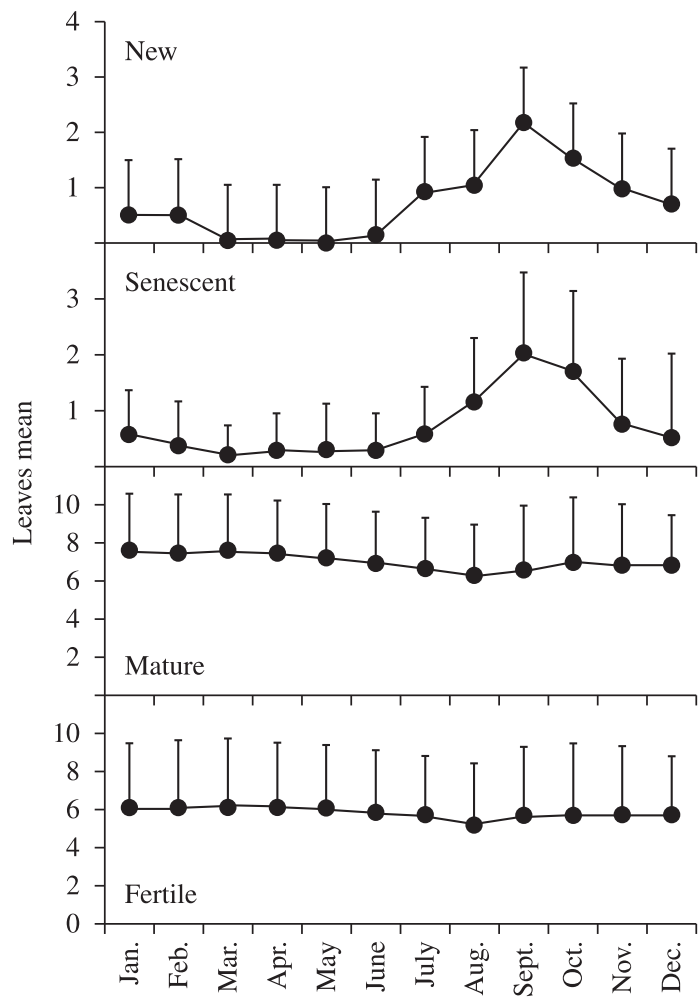

Figure 2. Monthly mean of new, senescent, mature and fertile leaves per plant of Cyathea atrovirens, from January to December 2004, in a secondary forest formation in southern Brazil. Bars indicate standard deviation. 
index $(Z=0.86)$. Croziers $(n=29)$ of Cyathea atrovirens expanded faster in the first $\left(2.53 \pm 0.93 \mathrm{~cm}_{\text {day }}{ }^{-1}\right)$ and second $\left(1.50 \pm 0,91 \mathrm{~cm} . \mathrm{day}^{-1}\right)$ month after emergence. After the 60 days, only 15 leaves continued to increase in

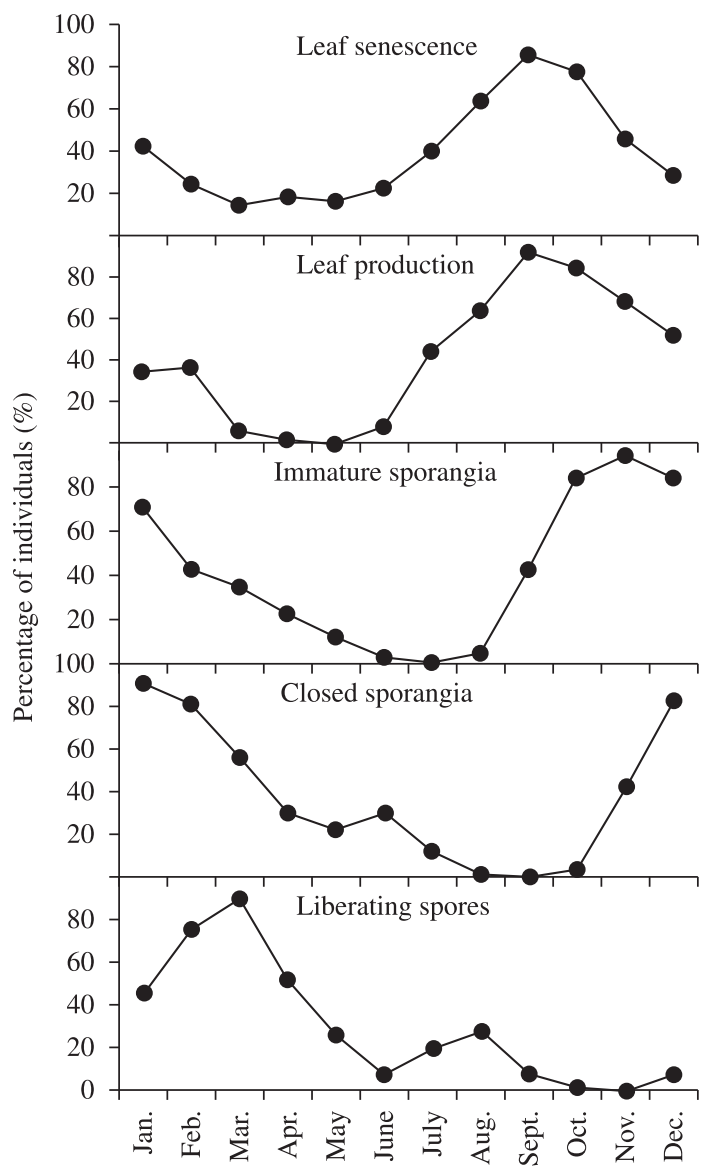

Figure 3. Monthly percentage (\%) of Cyathea atrovirens individuals showing leaf senescence and new leaf production; leaves with immature, closed sporangia and liberating spores, from January to December, 2004, in a secondary forest formation in southern Brazil. length, although at a slower rate $\left(0.29 \pm 0.56 \mathrm{~cm}^{-d_{a y}}{ }^{-1}\right)$. Maximum crozier expansion rate was $5.18 \mathrm{~cm}^{-d_{a y}{ }^{-1}}$ in the first month. One crozier during winter (August 2004), and three in summer (January 2005), died. Minimum, maximum and medium leaf length was 71, 272 and $157.36 \pm 39.31 \mathrm{~cm}(n=50)$, respectively. During the 12 months, the minimum and maximum numbers of leaves per sporophyte fully expanded with green pinnae (mature) were one and 16, respectively. However, plants with senescent leaves were observed during all year. Leaves senesced at a rate of $8.76 \pm 4.25$ leaves per plant.year ${ }^{-1}$, ranging from 3 to 27 leaves per plant.year ${ }^{-1}$. In the spring, the highest monthly mean rates of senescent leaf production were observed, with a maximum mean of $2.02 \pm 1.44$ leaves per plant recorded in September (Figure 2). After the late winter, in September and October $\geq 78 \%$ of the population had senescent leaves (Figure 3 ), with a synchrony index higher than the annual value $(Z=0.82)$. In September of 2004 the highest rainfall was recorded together with a higher frequency of individuals with leaf emergence (92\%) and senescence (86\%), although these phenological events did not correlate with precipitation in the same manner as with temperature and photoperiod (Figure 3 and Table 1).

Production of new spores occurred during all months of 2004 except July, resulting in $\mathrm{Z}=0.66$. In spring the highest frequencies of individuals producing spores (immature sporangia) was observed, reflecting an increase in the index of synchrony to 0.84 in the period from October to December 2004. In winter, on the other hand, spore production was low and, consequently, the frequency of plants with closed sporangia was also very low from August to October. Most individuals had leaves with closed sporangia during the summer (January and February), reflected by synchrony index $(Z=0.83)$ higher than the yearly one $(Z=0.67)$ and in late spring, in December 2004 (Figure 3). The frequency of individuals with immature and closed sporangia correlated positively and strongly with temperature and photoperiod (Table 1). Spore release occurred from January to December 2004, except in November. During summer (February and March), the highest frequencies of individuals releasing spores were recorded (Figure 3),

Table 1. Spearman rank correlations $(r)$ between phenological events of Cyathea atrovirens and environmental variables, from January to December 2004, in a secondary forest formation in southern Brazil. ${ }^{*} \mathrm{p}<0.05 ; * \mathrm{p}<0.01$; ns $=$ non-significant.

\begin{tabular}{lccc}
\hline \multicolumn{1}{c}{ Phenological events } & Temperature $\left({ }^{\circ} \mathbf{C}\right)$ & Precipitation $(\mathbf{m m})$ & Photoperiod $(\mathbf{h})$ \\
\hline Mean monthly new leaves per plant & $-0.19 \mathrm{~ns}$ & $0.29 \mathrm{~ns}$ & $0.24 \mathrm{~ns}$ \\
Mean monthly senescent leaves per plant & $-0.15 \mathrm{~ns}$ & $0.32 \mathrm{~ns}$ & $0.32 \mathrm{~ns}$ \\
Mean monthly mature leaves per plant & $\mathbf{0 . 6 9 *}$ & $-0.29 \mathrm{~ns}$ & $0.28 \mathrm{~ns}$ \\
Mean monthly fertile leaves per plant & $\mathbf{0 . 6 4 *}$ & $-0.39 \mathrm{~ns}$ & $0.18 \mathrm{~ns}$ \\
$\begin{array}{l}\text { Relative frequency of individuals with } \\
\text { immature sporangia }\end{array}$ & $\mathbf{0 . 6 7 *}$ & $0.09 \mathrm{~ns}$ & $\mathbf{0 . 9 1 * *}$ \\
$\begin{array}{l}\text { Relative frequency of individuals with } \\
\text { closed sporangia }\end{array}$ & $\mathbf{0 . 8 2 * *}$ & $-0.41 \mathrm{~ns}$ & $\mathbf{0 . 6 3 *}$ \\
$\begin{array}{l}\text { Relative frequency of individuals spore } \\
\text { liberation }\end{array}$ & $0.35 \mathrm{~ns}$ & $-0.46 \mathrm{~ns}$ & $-0.56 \mathrm{~ns}$ \\
\hline
\end{tabular}


Table 2. Minimum, maximum and mean mature and fertile leaf number, from January (2004-09) of Cyathea atrovirens in secondary forest, southern Brazil. Means with different letters are significantly different (Bonferroni test, $\alpha=0.05$ ). SD: standard deviation; d.f.: degrees of freedom; F: value of the Snedecor distribution; $P$ : Probability.

\begin{tabular}{|c|c|c|c|c|c|c|}
\hline & Minimum & Maximum & Mean \pm SD & d.f. & $\mathbf{F}$ & $P$ \\
\hline \multicolumn{7}{|l|}{ Mature leaves } \\
\hline January 2004 & 3 & 15 & $7.52 \pm 3.04 a$ & 5 & 13.95 & $<0.001$ \\
\hline January 2005 & 4 & 16 & $7.42 \pm 2.72 b$ & & & \\
\hline January 2006 & 3 & 16 & $6.52 \pm 2.42 \mathrm{c}$ & & & \\
\hline January 2007 & 2 & 16 & $6.06 \pm 2.41 \mathrm{de}$ & & & \\
\hline January 2008 & 2 & 11 & $5.73 \pm 2.15 \mathrm{e}$ & & & \\
\hline January 2009 & 2 & 12 & $6.71 \pm 2.51 \mathrm{abcd}$ & & & \\
\hline \multicolumn{7}{|l|}{ Fertile leaves } \\
\hline January 2004 & 0 & 13 & $6.13 \pm 3.39 \mathrm{ab}$ & 5 & 7.77 & $<0.001$ \\
\hline January 2005 & 0 & 16 & $6.29 \pm 3.27 a$ & & & \\
\hline January 2006 & 1 & 16 & $5.56 \pm 2.68 b c$ & & & \\
\hline January 2007 & 0 & 16 & $4.77 \pm 2.70 \mathrm{~d}$ & & & \\
\hline January 2008 & 0 & 11 & $4.90 \pm 2.71 \mathrm{~cd}$ & & & \\
\hline January 2009 & 0 & 12 & $6.13 \pm 2.95 \mathrm{ab}$ & & & \\
\hline
\end{tabular}

Table 3. Minimum, maximum and annual growth mean rate of Cyathea atrovirens in secondary forest, southern Brazil. Means with different letters are significantly different (Bonferroni test, $\alpha=0.05$ ). SD: standard deviation; d.f.: degrees of freedom; F: value of the Snedecor distribution; $P$ : Probability.

\begin{tabular}{|c|c|c|c|c|c|c|}
\hline Period & $\begin{array}{l}\text { Minimum growth } \\
\text { rate }\left(\mathrm{cm} \cdot \text { year }^{-1}\right)\end{array}$ & $\begin{array}{l}\text { Maximum growth } \\
\text { rate }\left(\mathrm{cm} . \text { year }^{-1}\right)\end{array}$ & $\begin{array}{c}\text { Annual growth rate } \\
\text { mean } \pm \text { SD }\left(\mathrm{cm}^{2} \text { year }^{-1}\right)\end{array}$ & d.f. & $\mathbf{F}$ & $P$ \\
\hline $1^{\circ}$ Jan. (2004-05) & 0 & 10 & $2.50 \pm 1.94 \mathrm{a}$ & 4 & 6.61 & $<0.001$ \\
\hline $2^{\circ}$ Jan. (2005-06) & 0 & 6 & $1.19 \pm 1.27 \mathrm{~b}$ & & & \\
\hline $3^{\circ}$ Jan. (2006-07) & 0 & 6 & $1.21 \pm 1.13 b$ & & & \\
\hline $4^{\mathrm{o}} \mathrm{Jan} .(2007-08)$ & 0 & 8 & $2.27 \pm 2.29 \mathrm{ab}$ & & & \\
\hline $5^{\circ}$ Jan. (2008-09) & 0 & 8 & $1.46 \pm 2.08 b$ & & & \\
\hline
\end{tabular}

Table 4. Annual production and leaf expansion rates of tree ferns from southern Brazil and other neotropical Cyathea spp.

\begin{tabular}{cccc}
\hline Species & $\begin{array}{c}\text { Annual leaf production rate } \\
\left(\text { leaves per plant.year }{ }^{-1}\right)\end{array}$ & $\begin{array}{c}\text { Leaf expansion rate } \\
\left(\mathbf{c m . d a y}^{-1}\right)\end{array}$ & Site \\
\hline Cyathea caracasana $^{\mathrm{a}}$ & 5.09 & - & Colombia \\
Cyathea pubescens, $^{\mathrm{b}}$ & 8.0 & 4.94 & Jamaica \\
Dicksonia sellowiana $^{\mathrm{d}}$ & 10.86 & 3.45 & Brazil \\
Cyathea atrovirens $^{\mathrm{e}}$ & $\mathbf{8 . 6}$ & $\mathbf{5 . 1 8}$ & Brazil \\
Cyathea delgadii $^{\mathrm{f}}$ & 5.75 & 6.71 & Brazil \\
Alsophila setosa $^{\mathrm{g}}$ & 5.51 & 7.48 & Brazil \\
\hline
\end{tabular}

${ }^{\mathrm{a}}$ Arens, 2001; ${ }^{\mathrm{b}}$ Tanner, 1983 ; ${ }^{\mathrm{C} S h r e v e, ~} 1914$; ${ }^{\mathrm{d}} \mathrm{Schmitt}$ et al., 2009; ${ }^{\mathrm{e}}$ present study; ${ }^{\mathrm{f}}$ Schmitt and Windisch, 2007; ${ }^{\mathrm{g}} \mathrm{Schmitt}$ and Windisch, 2006b

resulting in a high synchrony $(Z=0.84)$ for the period, higher than throughout the year $(Z=0.62)$. Nonetheless spore release did not correlate with the climatic variables. Temperature was the single climatic variable that affected the mature and fertile leaves means per plant (Table 1). A relationship between plant height and monthly mean of fertile leaves was not observed $\left(r_{\mathrm{s}}=0,11 ; \mathrm{p}=0,46 ; \mathrm{n}=50\right)$.
All monitored individuals were fertile with caudices at least $10 \mathrm{~cm}$ tall.

Annual monitoring - Monitored plants had a decreasing and statistically different sequence among them in mature leaf means from January 2004 to 2008, except from those recorded in 2007-08. Only in January 2007 and 2008 plants showed lower fertile leaf means that were 
significantly different from those recorded during the first year of observation. Yet, the coinciding means of mature and fertile leaves in January 2004 and January 2009 point toward the maintenance of a constant number of leaves during the monitoring period (Table 2). In average the caudices of Cyathea atrovirens grew significantly more during the first year compared to the second, third and fifth year of observation. Following this period, from the second year on, plants showed a more uniform growth, with no significant differences. The maximum growth was $10 \mathrm{~cm}$ year $^{-1}$ (Table 3), recorded only in the first period (January 2004-05). During the five years of study, all individuals showed an increase in height. Individual mortality was low (4\%): two dead plants in 2007 and 2008 , respectively.

\section{Discussion}

Cyathea atrovirens had a slow and relatively constant growth under a forest canopy, following similar climatic conditions during the years of monitoring. In this study, the mean height increase rate of this species during five years was considerably lower than that recorded for other tree ferns in Rio Grande do Sul: Alsophila setosa Kaulf. $\left(6.32 \mathrm{~cm}\right.$ year $\left.{ }^{-1}\right)$ and $C$. delgadii Sternb. (4.65 cm.year $\left.{ }^{-1}\right)$ by Schmitt and Windisch (2006a, 2007), growing in secondary semideciduous seasonal forest formations; and Dicksonia sellowiana Hook. (4.11 cm.year ${ }^{-1}$ ) in the contact area between seasonal semideciduous forest and mixed humid forest by Schmitt et al. (2009). Lehn and Leuchtenberger (2008) studied a population of $C$. atrovirens growing in a location fully exposed to sunlight after exposure to fire through the burning of the underbrush and observed a mean caudex growth of $8.4 \mathrm{~cm}_{\text {.year }}{ }^{-1}$. The ashes may have released nutrients into the soil, allowing the plants to grow faster during the year following the burn, although probably decreasing in the subsequent years. This result contrasted with our observations of slow growth, which is an example of the influence of external conditions and an intra-specific variation on growth patterns. The mean height increase rate of $C$. atrovirens is also significantly smaller than the values recorded for other neotropical tree ferns of this genus growing in secondary forests: C. arborea (L.) Sm. (28.6 cm.year ${ }^{-1}$ ) by Conant (1976); C. delgadii $\left(81.9 \mathrm{~cm}^{-y e a r^{-1}}\right.$ ) and C. trichiata (Maxon) Domin (89.7 cm.year ${ }^{-1}$ ) by Bittner and Breckle (1995); C. caracasana (Klotzsch) Domin (16.8 cm.year ${ }^{-1}$ ) by Arens (2001). This demonstrates the large interspecific variation in tree fern growth as already cited by Arens (2001); Schmitt and Windisch (2007). The slow growth might have been due to the proximity of the studied ferns to the stream, which usually limits the capacity of the litter to decompose and release nutrients into the soil.

Slow growth rates do not exclude the possibility of cultivation. Hoehne (1930) observed that Cyathea atrovirens is a rustic plant, with decorative leaves, easily grown even when planted in exposed sites, being able to stand direct sunlight. The species may present heliomorphic characters such as leathery shiny laminar tissue (Fernandes, 1997), adapting well to different environmental conditions. This is reflected by its wide distribution and occurrence in diverse hatitats. Furthermore, the low percentage of adults killed by natural causes, observed in the present study, indicates that individuals of this species, once established, may last for many years. Nevertheless, no information was obtained on the cultivation of $C$. atrovirens for commercial and landscaping projects in southern Brazil, although it is used in areas where it can be harvested in nature.

Values of annual leaf production and expansion rates for Cyathea atrovirens correspond to those recorded for other neotropical tree ferns. The highest expansion rate recorded by Shreve (1914) for C. pubescens growing in the humid mountain forests of Jamaica, comes close to the values recorded in the present study (Table 4). Different expansion rates in different stages of leaf development observed here in $C$. atrovirens seems to be a pattern among tree ferns in southern Brazil, which was also observed in Alsophila setosa, C. delgadii (Schmitt and Windisch 2006b, 2007) and Dicksonia sellowiana (Schmitt et al., 2009). Leaf senescence and emergence in the studied population of C. atrovirens was continuous throughout the year due to heterogeneity in individual patterns. The period of highest synchrony of these phenological events was during spring, thus preventing total leaf abscission. This continuous leaf phenology pattern was also observed for $C$. delgadii (Schmitt and Windisch, 2007) and Dicksonia sellowiana (Schmitt et al., 2009) in Rio Grande do Sul, Brazil, and for C. pubescens (Tanner, 1983), in Jamaica. Croziers, protected by a layer of light brown to ferruginous scales, were resistant to winter low temperatures and to summer heat, with one and three croziers necrosed in the cold and in the warm season of 2004, respectively. In addition to physical protection of the apical meristem, scales can moisturise the tissue by absorbing water from rain, fog or condensation while keeping humid air around the tissues (see Barrington, 1978; Tryon and Tryon, 1982).

During spring, with increased rainfall, higher temperatures and extended photoperiod, there was a higher frequency of individuals producing new and senescent leaves. Nonetheless this observation was not reflected in a correlation of leaf emergence and senescence with climatic variables. In another tree ferns species of Rio Grande do Sul, such as Cyathea delgadii (Schmitt and Windisch, 2007) and Dicksonia sellowiana (Schmitt et al., 2009) leaf production and senescence showed no relationship with precipitation, temperature or photoperiod. Precipitation affects the activity of plants in strongly seasonal forests (van Schaik et al., 1993) and although rainfall varied over the first year of this study, there was not a defined dry season. The pressure of herbivores and competition processes are some of the determinants of plant phenology in environments with less seasonal climates (Aide, 1988) that may have influenced the senescence and emergence of leaves in the studied population of $C$. atrovirens. Endogenous periodic processes work, primarily on the reproduction and growth 
of tropical plants, while the environmental changes are secondary factors of influence (Borchert, 1980).

The cold had a restrictive effect on the number of mature and fertile leaves of Cyathea atrovirens, seeing that temperature was the only variable correlated with leaf monthly means. Mean numbers of mature and fertile leaves increased slowly and gradually after a highly synchronous leaf emergence during spring, following the increase in mean monthly temperatures. Monthly mature and fertile leaf means of $C$. atrovirens varied slightly during the first year of observation because leaf emergence overlapped with senescence. Although periods of reduction in the annual mean of mature and fertile leaves were observed during the five years of monitoring, means for January 2004 and January 2009 were statistically equivalent. Thus it is possible that tree fern individuals can maintain a relatively stable number of leaves over a long period of time. A similar pattern was observed for a Dicksonia sellowiana population (Schmitt et al., 2009), where monthly means of mature leaves were correlated with temperature and, during a three-year period, plants maintained their number of leaves practically stable.

During the five years of monitoring, one $2 \mathrm{~m}$ tall plant with the maximum number of leaves (16) gradually tilted until it touched the ground and then redirected its crown of leaves vertically. This growth pattern with regeneration after toppling offers a potential for continuous growth (Windisch et al., 2008), reducing the risk of mortality of individual plants. The mantle of adventicious roots at the caudex base may partially function to provide support in the same way as the secondary structure of woody trunk in angiosperms (Ogura, 1972), although with less efficiency (Mehltreter and García-Franco, 2008).

All marked plants produced at least some fertile leaves during the study indicating that the Cyathea atrovirens population has favourable conditions for its development in the studied forest formation. However this population structure, with all (100\%) individuals producing spores, is not common among tree ferns when compared with data from other studies such as Nagano and Suzuki (2007) in C. spinulosa Wall. ex Hook. (33\%) from Japan; Mehltreter and García-Franco (2008) in Alsophila firma (25\%) from Mexico; Schmitt and Windisch (2006b) in A. setosa (8.88\%); Schmitt and Windisch (2007) in C. delgadii (9.75\%) and Schmitt et al. (2009) in Dicksonia sellowiana (38\%), from southern Brazil. This suggests $C$. atrovirens is potentially a great competitor, being able to increase population size in the study forest, where habitat conditions are not adverse. Among the four tree fern species recorded by Schmitt and Goetz (2010), C. atrovirens was the only one with generalised occurrence at Henrique Luís Roessler Municipal Park. Page (1979) emphasized that the production of spores may be high when the plant is competing with others, and perhaps, when the group reaches maturity.

Spore production was not related to age/size of plants as we did not find a tendency in taller plants to have more fertile leaves. The lack of influence of height on the fertility of Cyathea atrovirens may be related to the fact that the population is in a secondary forest, where the scarce canopy cover provides an increase in duration and intensity of the light that reaches the understory, thus decreasing the competition for this resource.

Longer day-lengths and higher temperatures seem to promote fertility as the number of plants with immature closed sporangia increased during spring. This observation indicates a positive correlation among these climatic variables and suggests that Cyathea atrovirens might be favoured by global warming. Sato (1982) observed that lower temperatures may restrict spore production. In the present study no plants with new spores were observed during the coldest month of 2004 (July). Populations of Cibotium taiwanensis Kuo CM (Chiou et al., 2001) and Dicksonia sellowiana (Schmitt et al., 2009), growing in places where there is not a defined dry season as well, had a spore production phenology more influenced by temperature and day length than by rainfall. These two climatic variables seem more important to the phenology of plants in localities where the environment is humid throughout the year (Morellato et al., 2000). Spore release in $C$. atrovirens was not related to rainfall, photoperiod or temperature. Considering that spore dispersal was not limited by the climatic variables, wind might have a relation to this phenological event, although it was not investigated in this study.

Spore production and release, occurring throughout the year, even if with an inconstant frequency, increases the possibility of recruitment of new individuals in the population. This avoids the loss of the whole or most of the spore production in case of unfavorable events, also allowing a higher colonisation potential of newly exposed microhabitats (Ranal, 1995).

Acknowledgements - The authors acknowledge the support of the Federal University of Rio Grande do Sul - UFRGS, University of Novo Hamburgo - FEEVALE, University of Vale do Rio dos Sinos - UNISINOS and Brazilian Research Council - CNPq (grant to the second author). Cristina L. J. Schmitt, friends and students provided welcome help on the project activities. Dr. Joanne Sharpe kindly revised the preliminary manuscript presenting relevant comments and suggestions.

\section{References}

AIDE, TM., 1988. Herbivory as a selective agent on the timing of leaf production in a tropical understory community. Nature, vol. 336, p. 574-575. http://dx.doi.org/10.1038/336574a0

ARENS, NC., 2001. Variation in performance of the tree fern Cyathea caracasana (Cyatheaceae) across a sucessional mosaic in Andean cloud forest. American Journal of Botany, vol. 88, no. 3, p. 545-551. http://dx.doi.org/10.2307/2657118

AUGSPURGER, CK., 1983. Offspring recruitment around tropical trees: changes in cohort distance with time. Oikos, vol. 40, no. 2, p. 189-196. http://dx.doi.org/10.2307/3544582

BARRINGTON, DS., 1978. A revision of the genus Trichipteris. Contributions from the Gray Herbarium of Harvard University, vol. 208, p. 3-91.

BITTNER, J. and BRECKLE, SW., 1995. The growth rate and age of tree fern trunks in relation to habitats. American Fern Journal, vol. 85, no. 2, p. 37-42. http://dx.doi.org/10.2307/1547463 
BORCHERT, R., 1980. Phenology and ecology of a tropical tree Erythryna poeppigiana. Ecology, vol. 65, no. 5, p. 1065-1074. http://dx.doi.org/10.2307/1936825

CHIOU, WL., LIN, JC. and WANG, J., 2001. Phenology of Cibotium taiwanense (Dicksoniaceae). Taiwan Journal for Science, vol. 16, no. 4, p. 209-215.

CONANT, DS., 1976. Ecogeographic and systematic studies in American Cyatheaceae. Cambridge: Harvard University. Tese de Doutorado.

FERNANDES, I., 1997. Taxonomia e fitogeografia de Cyatheaceae e Dicksoniaceae nas regiões sul e sudeste do Brasil. São Paulo: Universidade de São Paulo. Tese de Doutorado.

-, 2000. Taxonomia dos representantes de Dicksoniaceae no Brasil. Pesquisas Botânica, vol. 50, no. 1, p. 5-26.

-, 2003. Taxonomia dos representantes de Cyatheaceae do nordeste oriental do Brasil. Pesquisas Botânica, vol. 53, no. 1, p. 7-53.

FONTANA, JL., RODRÍGUEZ, ME., CARDOZO, AE. and IRIART, D., 2007. Confirmación de la presencia de Cyathea atrovirens (Cyatheaceae) en la província de Corrientes, Argentina. Boletín de la Sociedad Argentina de Botánica, vol. 42, no. 3-4, p. 325-327.

HOEHNE, FC., 1930. As plantas ornamentaes da flora brasílica e o seu papel como factores da salubridade publica, da esthética urbana e artes decorativas nacionaes. Separata do Boletim de Agricultura, Secretaria da Agricultura, Indústria e Comércio do Estado de São Paulo, p. 115-130.

LEHN, CR. and LEUCHTENBERGER, C., 2008. Resistência ao fogo em uma população de Cyathea atrovirens (Langsd. \& Fisch.) Domin (Cyatheaceae) no Estado do Rio Grande do Sul, Brasil. Biotemas, vol. 21, no. 3, p. 15-21.

MEHLTRETER, K., 2006. Leaf phenology of the climbing fern Lygodium venustum in a semideciduous lowland forest on the Gulf of Mexico. American Fern Journal, vol. 96, no. 1, p. 21-30. http:// dx.doi.org/10.1640/0002-8444(2006)96[21:LPOTCF]2.0.CO;2

MEHLTRETER, K. and GARCÍA-FRANCO, JG., 2008. Leaf phenology and trunk growth of the deciduous tree fern Alsophila firma (Baker) D. S. Conant in a Lower montane mexican forest. American Fern Journal, vol. 98, no. 1, p. 1-13. http://dx.doi. org/10.1640/0002-8444(2008)98[1:LPATGO]2.0.CO;2

MEHLTRETER, K. and PALACIOS-RIOS, M., 2003. Phenological studies of Acrostichum danaeifolium (Pteridaceae, Pteridophyta) at a mangrove site on the Gulf of México. Journal Tropical Ecology, vol. 19 , no. 2 , p. $155-162$.

MORELLATO, LPC., TALORA, DC., TAKAHASI, A., BENCKE, CC., ROMERA, EC. and ZIPARRO, VB., 2000. Phenology of Atlantic Rain Forest trees: a comparative study. Biotropica, vol. 32 , no. 4b, p. 811-823.

MORENO, JA., 1961. Clima do Rio Grande do Sul. Porto Alegre: Secretaria da Agricultura.

NAGANO, T. and SUZUKI., 2007. Leaf demography and growth pattern of the tree fern Cyathea spinulosa in Yakushima Island. Tropics, vol. 16, no. 1, p. 47-57. http://dx.doi.org/10.3759/ tropics. 16.47

OGURA, Y., 1972. Comparative anatomy of vegetative organs of the Pteridophytes. Berlin: Gebrüder Bornträger.

PONCE, M., 1996. Pteridophyta. In ZULOAGA, FO. and MORRONE, O. (Eds.). Catálogo de las plantas vasculares de Argentina I: Pteridophyta, Gymnospermae y Angiospermae
(Monocotyledoneae). Monographs in Systematic Botany from the Missouri Botanical Garden, vol. 60, p. 1-79.

PAGE, CM., 1979. Experimental aspects of fern ecology. In DYER, AF. The experimental biology of ferns. London: Academic Press. p. 552-581.

PEDRONI, F., SANCHEZ, M. and SANTOS, FAM., 2002. Fenologia de copaíba Copaifera langsdorffii Desf. - Leguminosae, Caesalpinioideae) em uma floresta semidecídua no sudeste do Brasil. Revista Brasileira de Botânica, vol. 25, no. 2, p. 183-194.

RANAL, MA., 1995. Estabelecimento de pteridófitas em mata mesófila semidecídua do Estado de São Paulo. 3. Fenologia e sobrevivência dos indivíduos. Revista Brasileira de Biologia, vol. 55, no. 4, p. 777-787.

RECHENMACHER, C., SCHMITT, JL. and DROSTE, A., 2010. Spore germination and gametophyte development of Cyathea atrovirens (Langsd. \& Fisch.) Domin (Cyatheaceae) under different pH conditions. Brazilian Journal of Biology, vol. 70, no. 4 (suppl.), p. 1155-1160. http://dx.doi.org/10.1590/S151969842010000600004

REICH, PB. and BORCHERT, R., 1984. Water stress and tree phenology in a tropical dry forest in the lowlands of Costa Rica. Journal of Ecology, vol. 72, no. 1, p. 61-74. http://dx.doi. org/10.2307/2260006

RICHARDS, PW., 1952. The tropical rain forest: an ecological study. Cambridge: Cambridge University Press. 450 p.

SANT'ANNA, JR., MIGUEL, OG. and ALQUINI, Y., 2001. Estudo morfo-anatômico de Trichipteris atrovirens (Langsd. et Fisch) Tryon. (Cyatheaceae). Revista Visão Acadêmica, vol. 2, no. 2, p. 59-64.

SATO, T., 1982. Phenology and wintering capacity of sporophytes and gametophytes of ferns native to Northern Japan. Oecologia, vol. 55, no. 1, p. 53-61. http://dx.doi.org/10.1007/BF00386718

SCHMITT, JL. and GOETZ, MNB., 2010. Species richness of fern an lycophyte in a urban park in the Rio dos Sinos basin, Southern Brazil. Brazilian Journal of Biology, vol. 70, no. 4, p. 1161-1167. http://dx.doi.org/10.1590/S1519-69842010000600005

SCHMITT, JL., SCHNEIDER, PH. and WINDISCH, PG., 2009. Crescimento do cáudice e fenologia de Dicksonia sellowiana Hook. (Dicksoniaceae) no sul do Brasil. Acta Botanica Brasilica, vol. 23, no. 1, p. 289-291

SCHMITT, JL. and WINDISCH, PG., 2001. Prejuízos causados pela geada no desenvolvimento de Alsophila setosa Kaulf. (Pteridophyta, Cyatheaceae). Revista de estudos / Universidade Feevale, vol. 24, no. 1, p. 79-88.

-, 2003. Relação entre comprimento do estípite, produção de frondes e tamanho do cáudice, em Alsophila setosa Kaulf. (Pteridophyta, Cyatheaceae). Pesquisas Botânica, vol. 53, no.1, p. 55-63.

-, 2006a. Growth rates and age estimates of Alsophila setosa Kaulf. in southern Brazil. American Fern Journal, vol. 96, no. 4, p. 103-111. http://dx.doi.org/10.1640/0002-8444(2006)96[103:GR AAEO]2.0.CO;2

-, 2006b. Phenological aspects of frond production in Alsophila setosa Kaulf. (Cyatheaceae: Pteridophyta) in southern Brazil. Fern Gazette, vol. 17, no. 5, p. 263-270.

-, 2007. Estrutura populacional e desenvolvimento da fase esporofitica de Cyathea delgadii Sternb. (Cyatheaceae, Monilophyta) no sul do Brasil. Acta Botanica Brasilica, vol. 21, no. 3, p. 731-740. http://dx.doi.org/10.1590/S0102-33062007000300019 
SEHNEM, A., 1978. Ciateáceas: Flora Ilustrada Catarinense. Itajaí: Herbário Barbosa Rodrigues.

SHREVE, F., 1914. A Montane Rain-Forest: A contribution to the physiological plant geography of Jamaica. Washington: Carnegie Institution of Washington.

TANNER, EVJ., 1983. Leaf demography and growth of tree-fern Cyathea pubescens Mett. Ex Kuhn in Jamaica. Botanical Journal of the Linnean Society, vol. 87, no. 3, p. 213-227. http://dx.doi. org/10.1111/j.1095-8339.1983.tb00991.x

TRYON, R. and TRYON, A., 1982. Ferns and allied plants with special reference to Tropical America. New York: Springer Verlag.

VAN SCHAIK, CP., TERBORGH, JW. and WRIGHT, SJ., 1993.

The phenology of tropical forest: adaptive significance and consequences for primary consumers. Annual Review of ecology and Systematics, vol. 24, no. 1, p. 353-377.

WALKER, LR. and APLET, GH., 1994. Growth and fertilization responses of Hawaiian Tree Ferns. Biotropica, vol. 26, no. 4, p. 378-383. http://dx.doi.org/10.2307/2389231

WEISHEIMER, C., MAUHS, J. and SAUL, PFA., 1996. Plano de Manejo: Parque Municipal Henrique Luís Roessler. Novo Hamburgo: Prefeitura Municipal de Novo Hamburgo.

WINDISCH, PG., NERVO, MH. and SEIBERT, S., 2008. Crescimento perene em Dicksonia sellowiana Hook. (Monilophyta, Dicksoniaceae). Pesquisas Botânica, vol. 59, no. 1, p. 287-297.1

ZAR, JH., 1999. Biostatistical analysis. New Jersey: Prentice-Hall. 
